\title{
Microbial electrochemical systems for sustainable biohydrogen production: Surveying the experiences from a start-up viewpoint
}

Gopalakrishnan Kumar ${ }^{1,2,3}$, Péter Bakonyi, ${ }^{4, *}$ Guangyin Zhen $^{5}$, Periyasamy Sivagurunathan ${ }^{6}$, László Koók ${ }^{4}$, Sang-Hyoun Kim ${ }^{2,3}$, Gábor Tóth ${ }^{4}$, Nándor Nemestóthy ${ }^{4}$, Katalin Bélafi-Bakó ${ }^{4}$

${ }^{1}$ Sustainable Management of Natural Resources and Environment Research Group, Faculty of Environmental and Labour Safety, Ton Duc Thang University, Ho Chi Minh City, Vietnam

${ }^{2}$ Department of Environmental Engineering, Daegu University, Gyeongsan, Gyeongbuk 712-714, Republic of Korea

${ }^{3}$ Sustainable Environmental Process Research Institute, Daegu University, Jillyang, Gyeongsan, Gyeongbuk 38453, Republic of Korea

${ }^{4}$ Research Institute on Bioengineering, Membrane Technology and Energetics, University of Pannonia, Egyetem ut 10, 8200 Veszprém, Hungary

${ }^{5}$ School of Ecological and Environmental Sciences, East China Normal University, Shanghai 200241, China

${ }^{6}$ Center for Material Cycles and Waste Management Research, National Institute for Environmental Studies, Tsukuba, Japan

${ }^{*}$ Corresponding Author: Péter Bakonyi

Tel: +3688624385

Fax: +36 88624292

E-mail: bakonyip@almos.uni-pannon.hu 


\begin{abstract}
The start-up of microbial electrohydrogenesis cells (MECs) is a key-step to realize efficient biohydrogen generation and adequate, long-term operation. This review paper deals with the lessons and experiences reported on the most important aspects of $\mathrm{H}_{2}$ producing MEC start-up. The comprehensive survey covers the assessment and discussion of the main influencing factors and methods (e.g. inocula selection, enrichment, acclimation, operating conditions and cell architecture) that assist the design of MECs. This work intends to be a helpful guide for the interested readers about the strategies employed to successfully establish microbial electrochemical cells for sustainable biohydrogen production.
\end{abstract}

Keywords: bioelectrochemical systems, microbial electrohydrogenesis cell, microbial electrolysis cell, microbial fuel cell, biohydrogen, start-up 


\section{Introduction}

In the last decade, bioelectrochemical systems (BES) have become an intensively studied platform technology in various fields of biotechnological processes [1]. BES are driven by special, electrochemically-active microorganisms to achieve goals such as (i) waste treatment to serve environmental remediation [2], (ii) the production of chemicals [3] and (iii) renewable energy recovery [4]. In the last aspect, microbial fuels cells (MFC) and microbial electrohydrogenesis cells (MEC) were shown as feasible approaches $[5,6]$. MECs are considered to combine MFC technology with electrolysis [7]. In both MFCs and MECs, bacteria work under anaerobic conditions at an anode to oxidize various substrates ranging from simple compounds i.e. sugars, organic acids [8] to complex organic matter including wastewaters of distinct origin [9-11] as well as fermentation effluents [12]. As a results, either bioelectric potential (in MFC) or $\mathrm{H}_{2}$ gas (in MEC) is obtained. It was lately argued based on life-cycle assessment that the conversion of organic feedstock to $\mathrm{bioH}_{2}$ in MECs is a highly attractive way to go from an environmental protection standpoint $[13,14]$, which suggests the potential contribution of this technology to sustainability.

In principles, MECs apply two electrodes (the anode and the cathode) under anaerobic circumstances [15]. The anode is the important place for exoelectrogenic strains that after colonizing its surface, form an anode-respiring biofilm. In essence, attributed to the metabolic activity of the biofilm, electrons and protons are released from 
successful substrate conversion/degradation. The electrons are transferred to the anode (as final electron acceptor) by different possible mechanisms (discussed later) and pass subsequently to the cathode via an external circuit. At the cathode, which plays the role of an electron donor, the reduction of $\mathrm{H}^{+}$to molecular $\mathrm{H}_{2}$ gas takes place. Unfortunately, this phenomena is non-spontaneous (thermodynamically not favored due to the positive Gibbs free-energy of the reaction) and therefore an external voltage, practically at least 0.2-0.25 V must be supplemented to make it happen (Fig. 1). The consecutive reactions (anodic substrate degradation and cathodic product $\left(\mathrm{H}_{2}\right)$ formation) can be either done in single- or two-chambered arrangement. In the latter case, the anode and cathode are spatially separated, in general by a membrane possessing ion-exchange capacity.

Basically, the achievable, steady-state performance of MECs depends strongly on the way it is started-up, which is known as a crucial step for $\mathrm{H}_{2}$ producing biotechnological systems [16]. The start-up could have a great importance to maximize the $\mathrm{H}_{2}$ production capacity of the MEC and should involve the establishment of efficient and robust biofilms [17-19]. To achieve adequate start-up, the source of inocula (containing the exoelectrogenic strains), consequent enrichment and acclimation methods to select bacteria with high bioelectrochmical activity seem to be of high concern since the characteristics of the anode-surface grown biofilm (i.e. its composition and state) determine the attractiveness of BES [20-23]. In addition to these biotic factors, the startup process ought to deal with the operating conditions (such as anodic potential, temperature, substrate and its concentration) and the cell architecture so as to positively 
influence the biofilm development and optimize the MEC from the point of view of $\mathrm{H}_{2}$ production rate/yield and other (energetic) process indicators e.g. Coulombic-efficiency, cathodic $\mathrm{H}_{2}$ recovery, current density, etc. However, even though the start-up is a keyelement for longer-term MEC viability [24], to our knowledge, no comprehensive article has been specifically dedicated to overview and assess the lessons and experiences gained in this field. Since MECs can be viewed as MFC-derived technologies with significant modifications on the cathode side, the start-up methods could reflect quite a number of similarities, especially related to the bioanode development [20]. Hence, in this paper, it was aimed to review the most essential factors and design considerations related to MEC start-up and give an insight to the progress how the recent accomplishments have improved the methodological approaches and enriched the international knowledge in this field.

\section{Effects of start-up variables on MEC performance}

\subsection{Inoculum for MEC start-up}

INOCULA containing anode-respiring bacteria can be delivered from various environments $[25,26]$ and dozens of strains were found to have sufficient capability for powering BES via biocurrent generation by (i) exocellular electron transfer relying either on membrane cytochromes, (ii) artificial/self-secreted mediators or (iii) electro- 
conductive appendages [27-29]. To select the microbial species (with appropriate electrochemical activity) to be used in biological fuel cells, a fast screening method was lately reported by Szöllősi et al. [30].

BES can apply both pure- and mixed cultures for inoculation. The use of pure isolates in bioelectrochemical applications could be important to conduct fundamental studies and to gain a better understanding about strain characteristics, behavior and functionalities (i.e. electron-transfer mechanism of the particular bacteria) [21]. Moreover, single-strains can be employed in the frame of bioaugmentation concept in order to reinforce mixed populations and obtain a better microbial equilibrium, which, in turn, leads to a higher capacity, exoelectrogenic biofilms and improved operational stability [20,31]. Systematic investigation and deeper comprehension on community ecology e.g. revealing the interactions in the fixed anodic-biofilms could be a valuable tool to enhance BES performance [22,32]. For instance, the syntrophy of anode-respiring bacteria with fermenting microorganisms seems to be advantageous [33] since the members of the latter class are able to efficiently decompose complex organic matter to simple compounds such as acetate, which represent easily biodegradable substrates for the former group.

Although pure culture BESs fit perfectly for principle studies, practical one should rely on mixed cultures. As concluded in the review by Liu et al. [27], these communities, in most cases, generate higher currents and provide better stability in comparison with single-strain systems. The further advantage of such communities could be the potential 
versatility and flexibility that are required for real-case, non-sterile applications. These could be good reasons behind the fact that microbial consortia appear to be more feasible to inoculate BES. Nevertheless, depending on the source of mixed inoculum, the reactor start-up and concomitant operational behavior e.g. in terms of process lag-phase can be significantly different [34]. Hence, to increase the probability of appropriate start-up and fair performance in longer-terms, techniques can be proposed for mixed culture microbial electrochemical cells that may result in an enriched consortia with better properties.

These enrichment methods (being either electrochemical or chemical) make it possible targeting specific groups of efficient exoelectrogenic species such as Geobacteraceae [35-37]. This preliminary selection, controlled growth and acclimation of biocatalysts could have substantial practical advantage since besides the physiological state of the bacterial cells $[38,39]$, the profile of the active microbial community developing on the anode during the start-up period is a factor that directly affects the MEC operation [40,41]. For instance, Boghani et al. [42] underlined that an optimized, electrochemical-strategy can be applicable to control biofilm enrichment, cut the start-up time demand and increase the capacity of the bioelectrochemical cell. Interestingly, Borjas et al. [38] demonstrated a 20-fold faster start-up period and a concurrent, 6-fold enhancement of COD removal during continuous MEC operation using chemostat(pre)grown, "plug and play" Geobacter culture instead of batch-grown cells. Thus, faster BES start-up seems to be possible employing pre-activated inoculum. 
In mixed culture BES, however, the competition of various microbial groups for ecological niche and substrate [43] e.g. between suspended-form (bulky phase) and anodophilic (electrogen) biocatalysts [9] may occur and can be seen as a notable constraint. Although non-exoelectrogens are expected to fail after a certain period of time because of the gradual dominance of their anode-surface located, bioelectrochemicallyactive counterparts [44], preventive actions so as to restrict undesired microbiological phenomena are advisable. It is noteworthy that apart from classical substrate (e.g. acetate) degradation, $\mathrm{H}_{2}$-scavenging reactions via interspecies hydrogen transfer e.g. by hydrogenotrophic methanogenesis could also take place in MECs $[45,46]$. Besides conventional and well-known methanogenesis, the $\mathrm{H}_{2}$-recycling effect is also to avoid, which means that a part of $\mathrm{H}_{2}$ evolved on the MEC cathode is utilized by bacteria on the anode i.e. to produce acetate via homoacetogenesis $[47,48]$. Besides, certain electrotroph microorganisms sticking to the cathode surface are able to capture the electrons transferred from the bioanode and directly convert them to methane via $\mathrm{CO}_{2}$ reduction [49-51], referred as electromethanosynthesis [52]. According to Sun et al. [53], further internal factors that can deteriorate BES performance are (i) biofouling and membrane blockage (obstructing proton transport to the cathode chamber), (ii) excessive anodic biofilm growth (causing non-conductive (dead) layers and limited substrate diffusion rate) and (iii) cathode inactivation due to the deposition of salt aggregates (partly occupying the reactive sites and blocking the proton transport to the surface). 
Typically, when the above-mentioned $\mathrm{H}_{2}$-consuming bioreactions and/or the consumption of organic materials through non-bioelectrochemical pathways cannot be neglected, the MEC performance, characterized by energetic process indicators i.e. Coulombic efficiency, current density, cathodic hydrogen recovery and actual $\mathrm{H}_{2}$ production rate undergo a decrease [54]. The Coulombic efficiency is a good tool to see what portion of the electrons liberated from oxidation of organic matter could be effectively captured by the anode and utilized in the bioelectrochemical reactions [55]. The amount of electrons reaching the anode (as terminal electron acceptor under anaerobic conditions) will influence the current (density), which is common measure to express the electrochemical activity of the biofilm [56] and determines the cathodic $\mathrm{H}_{2}$ recovery as well as the $\mathrm{H}_{2}$ production rate [24,57]. Apparently, to make MEC technology competitive with others existing in the field of renewable energy e.g. anaerobic digestion, as high efficiencies as possible should be attained for these parameters.

As implied, a part of biocatalyzed side-reactions in MECs is encountered due to the presence of methanogens (Fig. 2). In addition to the fact that methane formation can lower the overall efficiency of MECs, it can also be responsible for reactor off-gas contamination, which makes the downstream more complicated. This problem is more considerable in single-chamber devices where the anode and cathode reactions are not spatially separated. Nonetheless, even in MECs constructed in two-chambered design, gases could diffuse over time through the membrane placed in-between the anode and cathode compartments [58]. If it occurs, the hydrogen gas recovered at the cathode will 
contain impurities to be removed. To help the suppression of these unbeneficial organisms - in addition to the enrichment methods enlightened above - inoculum pretreatments i.e. by heat-shock, chemical inhibitors and $\mathrm{pH}$ adjustment were confirmed to eliminate/restrict methane-forming activity from mixed anaerobic communities [5961].

However, there are occasions when competing microorganisms, despite the careful efforts, survive for longer-terms by alternative metabolisms e.g. fermentation and methanogenesis [62]. For instance, Escapa and co-scientists [63] have communicated residual methanogenic activity in MECs inoculated with heat-shock pretreated culture. In such cases, overcoming strategies i.e. by regulating anode potentials can have a positive contribution to control the intensity of $\mathrm{CH}_{4}$ production and subsequently recover the system performance [64]. Furthermore, shortened MEC cycle time can also depress the methane formation activity [46]. Nonetheless, if considerable methanogenesis still exists i.e. due to the growth of archaea either on the reactor wall [65] or on the cathode, MEC re-start may be unavoidable.

Whether or not preliminary enrichment and/or seed pretreatment are carried out, MEC systems can be started-up by following two distinct approaches (Table 1): direct and indirect mode [66]. The former means one-step inoculation and adaption directly in the MEC, while the latter consists of a two-step, sequential procedure applying MFC as a first step to acclimate the biocatalysts and develop stable bioanodes. In this latter case, the steady, MFC-grown bioanodes can be transferred to the MEC device $[57,67]$. 
Interestingly, Liu et al. [15] found that the choice of MEC start-up mode can play an important role in preventing the growth of $\mathrm{CH}_{4}$-forming archaea. In their investigation, the observable methane production during the start-up of single-chamber MECs, running preliminary in MFC mode was much lower compared to MECs begun to operate directly (without the MFC stage). Besides, Wang et al. [68] demonstrated that it is also possible to switch between MFC and MEC modes in the same reactor employing a time-relay method.

From another aspect, (sequencing) batch mode operation represents the simplest and most routine way for BES start-up, although some authors succeeded with start-up carried out in continuous mode. For instance, Escapa et al. [69] used domestic wastewater as inocula for continuous flow MEC and the start-up period was performed in continuous mode (6 days long start-up, 12 h of HRT) and an extra 29 days were ensured to further stabilize the biofilm after observing the stabilization of current. Following a similar strategy, Tartakovsky et al. [70] investigated the hydrogen production in membraneless MEC started-up in a continuous mode at $10 \mathrm{~h}$ hydraulic retention time.

\subsection{The effect of operating variables on MEC start-up and its time demand}

The time requirement of start-up period in microbiological fuel cells should be as short as possible [71]. Nevertheless, it can be dependent on (i) the traits of the inoculum 
[71-73], (ii) the operating circumstances and (iii) the system architecture. Depending on the joint impact of these parameters, usual, system-specific start-up can last even for a couple of months [71]. Although the start-up of bioelectochemical systems seems to be laborious and time-consuming, some papers presented complete BES start-up only in several days $[44,71]$. Interestingly, Verea et al. [74] described a fast method for bioanode enrichment, which was done in 8 hours using $1 \mathrm{~V}$ voltage and facilitated MEC performance. In general, bioelectrochemical systems are considered to be started-up when performances (in particular steady-state voltages and current density profiles) are reproducible for a few (normally at least 3) consecutive (batch) cycles under the given operational conditions. Once such a state of the reactor is noted, it can be said that the anodic, exoelectrogenic biofilm is developed, mature enough [75] and accustomed to the reaction circumstances.

Since the significance of inoculum properties on start-up was already discussed in chapter 2.1., the following sections intend to present the role of (i) operating conditions and (ii) cell architecture on this critical phase of MEC operation.

\subsubsection{Anode potential}

Among the MEC operating variables, ANODE POTENTIAL is definitely a significant one and its adjustment can be precisely done using a potentiostat against a reference electrode (e.g. $\mathrm{Ag} / \mathrm{AgCl}, \mathrm{SCE}$ - standard calomel electrode, etc.). As concluded 
by Venkata Mohan and Lenin Babu [76], regardless of the transfer mechanism, the electrons released by the exoelectrogenic microoganisms have to move from higher negative potentials towards lower negative potentials. Thus, higher anode potentials will expectedly help the flow of electrons from the bacterial biofilm to the final terminal electron acceptor (anode). The relationship of the Gibbs free-energy with the potential difference between the electron (i) donor and (ii) acceptor suggests that higher energy can be gained by the cells via setting higher anode (electron acceptor) potentials. In other words, the potentials both of the anode and the terminal respiratory proteins will influence together the bacterial growth conditions and the amount of energy available for cell maintenance [77,78]. As summarized by Wagner et al. [77], literature studies demonstrate a general tendency of enhanced BES performance along with more positive anode potentials. For example, Wang et al. [73] demonstrated that positive posed potential on the anode $(+200 \mathrm{mV}$ vs. $\mathrm{Ag} / \mathrm{AgCl})$ was able to increase the activity of the electrochemical biofilm and thus, reduce the start-up time. The results showed that such strategy required $40 \%$ less time (35 days) in comparison with the control reactor (59 days) to get the system ready, without having significant differences in post start-up reactor performances. Similarly, Cho and Ellington [82] demonstrated the benefit of wellregulated anode potential conditions $(+500 \mathrm{mV}$ vs. $\mathrm{Ag} / \mathrm{AgCl}$ electrode), which resulted in the drastic (over 90\%) reduction of biofilm growth lag-phase. In another research, Aelterman et al. [83] drew supporting conclusions, as the outcomes indicated that an optimal anode potential can drive biofilm growth and activity, being accompanied by enhanced current generation and sustainable operation. Similarly, Commault et al. [84] 
highlighted that well-regulated anode potentials are useful to select efficient, Geobacterdominated biofilms and decrease the start-up time. However, it is noteworthy that even though many research works found better BES performance at higher anodic potentials, some others reported the preference of lower values [77]. Therefore, best anode potentials - defined as those resulting in high current densities and shorter start-up times - must be determined as a part of case-specific optimization due to factors (e.g. the composition of the microbial communities) that can vary from system to system) in order to help the development of proper anodophilic population and improve its $\mathrm{e}^{-}$discharge capability $[56]$.

In addition to the already described role that anode potential can have in BES, the value of fixed anodic (biofilm cultivation) potentials can metabolically stimulate the bacteria in a way that it may induce a switch in the electron transfer mechanism taking place between cells and the anode [79-81]. Furthermore, some researchers noticed a correlation between bacterial swimming speeds (using strains of Shewanella) and anode potential values [85] and it turned out also that carefully selected anodic potentials might have a beneficial effect in depressing methane formation activity [64], as implied above.

In summary, starting-up MEC systems with properly chosen anode potentials seems to be advantageous in promoting the colonization of anode by desired exoelectrogenic strains and in advancing robust bioanode formation [86]. Interestingly, Nam et al. [65] reported that strategies potentiostatically controlling the anode potential can be superior over simple "added voltage" operation using a DC power supply since it 
could result in a higher cathodic hydrogen production and shortened MEC cycle time. Nevertheless, the application of external (DC) power sources to provide sufficient voltage is still a widespread alternative for start-up MECs, and its value was proven to affect biohydrogen recovery in MEC using recalcitrant substrate e.g. liquid fraction of municipal solid waste in a recent study by Zhen et al. [122]. In another example, Heidrich et al. [87] described (>2 months) anode-biofilm acclimation method, during which the externally supplemented voltage was step-wise increased until decent $\mathrm{H}_{2}$ gas production could be observed. This start-up was proven successful and a stable biofilm could be obtained demonstrating a reliable performance in a long (1 year) interval [88]. In a paper by Jeremiasse et al. [89], MEC start-up took 3 weeks at $0.5 \mathrm{~V}$ applied cell voltage. Rozendal et al. [90] operated the MEC in start-up mode for 100 days, with a posed potential of $1 \mathrm{~V}$. In a work by Wang et al. [91], $0.6 \mathrm{~V}$ was used to establish the bioanode. Last but not least, in some articles [76,92], the adaption of bacteria and bioanode establishment was achieved without supplementing any external (DC or potentiostatic) power.

\subsubsection{Temperature effect on MEC start-up}

The ACCLIMATION TEMPERATURE could have a defining role in the dynamic selection and subsequent enrichment of anodophilic bacteria [93]. Consequently, the operational temperature of bioelectrochemical systems should be chosen in accordance with the properties of the inocula in order to maintain sufficient performances in longer 
terms. For example, as analyzed by Heidrich et al. [88], a likely cause for MEC failures can be the lack of sufficient adaption of mesophilic communities to lower temperatures. Additionally, operational temperature strongly regulates anode colonization [94]. In essence, the start-up time in bioelectrochemical cells was found to be in reverse relationship with system temperatures, while anodic biomass growth rate and accumulation showed a directly proportional correlation with elevated temperatures i.e. in the range of $10-35{ }^{\circ} \mathrm{C}$ [94]. For instance, MEC start-up time at $35^{\circ} \mathrm{C}$ could be shortened by $90 \%$ compared to $15{ }^{\circ} \mathrm{C}$ conditions [95]. Although it is commonly observed that MEC start-up increases with lower temperatures [94-96], findings about its effect on the final electrochemical activity of the bioanode are somewhat contradictory. For instance, in studies by Michie et al. [94] and Ahn and Logan [121] lower temperatures did not significantly affect the achievable, longer-term steady-state properties, meaning that of BESs acclimated at psychrophilic temperatures produced comparable voltages with mesophilic systems. In the case of the former study referred [94], a roughly 1 year process monitoring revealed that powers in MFCs operated at 10,20 and $35{ }^{\circ} \mathrm{C}$ were all around $0.23-0.24 \mathrm{~mW}$. On the other hand, Patil et al. [95] came to the conclusion that bioelectrocatalytic capacity of biofilms adapted at higher temperatures resulted in better, steady-state current densities. Noteworthy, even though greater biomass yield is generally reported with elevated temperatures, it can unfortunately be coupled with the improved proliferation of methanogenic archaea [94]. 
Overall, the analysis of literature indicates that the optimal temperature must always be determined for the specific MEC application. This should however be a tradeoff value that balances between (i) lag-phase time, (ii) anodic bioelectrochemical activity and (iii) methanogenic growth. Thus, at the expense of longer start-up phase, MECs acclimated and operated in the lower i.e. psychrophilic temperature range may be advantageous for the selective development of exoelectrogenically-active communities and simultaneous depression of competing organisms. Such psychrophilic MEC systems were shown to work well and produced decent amount of $\mathrm{H}_{2}$ gas [96], which is an attractive outcome since conventional $\mathrm{H}_{2}$ production methods i.e. by dark fermentation normally fail under low operational temperatures.

\subsubsection{Substrate and its concentration}

It was lately underlined that SUBSTRATE QUALITY and CONCENTRATION $[8,55]$ can play determining roles in microbial electrochemical cells. The substrates used in MEC [97], depending on their characteristics e.g. source and complexity, influence the anode-surface biofilm growth, the composition of the bacterial community and in the end, the efficiency indicators e.g. Coulombic efficiency. As reported by Sleutels et al. [55], lower substrate concentrations along with increased anodic potentials could be able to boost anodic biofilm activity, making them more competitive in longer-terms with nonelectrochemically useful microbes i.e. methanogens. 
During start-up period, acetate is a widely recognized compound to attain sufficient, anode-surface biofilm build-up. Nonetheless, in the course of practical, poststart-up MEC operation where recuperation of bioenergy from inexpensive/waste resources is among the primary objectives, the simple substrates are normally changed to complex, problematic organic matter e.g. the effluent of dark fermentative $\mathrm{H}_{2}$ producing bioreactors [98]. The feasibility of dark fermentation effluent (containing soluble metabolic products i.e. volatile fatty acids) for MEC set-ups was communicated in papers by Lalaurette et al. [99] and lately by Rivera et al. [12], as well (Fig. 1). According to such examples, it would appear that MECs hold the promise to be auxiliary (posttreatment) processes for classical dark fermentation in order to harness extra bioenergy (in the form of hydrogen) and thus, such combined applications can attract more attention to the emerging hydrogen energy sector.

As for substrate concentration, Escapa et al. [63] suggested a gradually-increased substrate loading for start-up to maintain its sufficient level but avoid its overdose causing an inhibition. In such a way, efficient stabilization of microbial bioanode was observed after 18-20 days. Furthermore, Liu et al. [71] studied the effects of medium amendments using compound such as acetate, fumarate, glucose and $\mathrm{Fe}(\mathrm{III})$ on the startup time of the wastewater-inoculated MFCs and summarized that the applied wastewater itself was appropriate for the acclimatization period without any added chemicals or amendments. 
In addition to the start-up of anodic biofilm, various authors took into account the development and application of $\mathrm{H}_{2}$-producing biological cathodes, as alternative solutions to regular (and costly) metal-based ones [14]. It was reported however that biocathode start-up is quite sophisticated compared to bioanodes [100]. To reduce its time demand, Jeremiasse et al. [101] investigated the effect of the substrate type and cathode potential on the start-up process in microbial electrolysis cell inoculated with aged MEC anodic cells. They found that acetate feeding instead of bicarbonate resulted in higher cathodic biomass yield and two times faster start-up, while the cathode potential had no significant influence.

\subsubsection{The cell architecture: anode and cathode materials, external and internal resistances}

The ELECTRODES are crucial components of bioelectrochemical systems. Conductive anode and cathode materials will not only affect the investment costs, but also the attachment of microorganisms to the surface. Hence, electrode properties, at least in part, determine the time needed for biofilm growth $[102,103]$ and as a consequence, the duration of start-up phase. Thus, their careful selection is a key-criteria for reactor design and stable operation. Anodes must be of biocompatible materials i.e. the already proven carbon or composites made of stainless steel [104], while chemical cathodes frequently contain platinum, nickel, stainless steel, etc. [105- 108] in order that $\mathrm{H}_{2}$ 
formation is properly catalyzed. Alternatively, microbial cathodes can represent a solution [109]. The anode properties i.e. mass and charge transport speed take a direct effect on the MEC performance [110]. The modifications of electrode surface by heat- or chemical treatment have been recently used in the field of BESs to alter surface charge, hydrophobicity, etc. For instance, Guo et al. [111] investigated the formation and composition of anodic biofilms growing on $-\mathrm{N}^{+}\left(\mathrm{CH}_{3}\right)_{3},-\mathrm{OH},-\mathrm{SO}_{3}{ }^{-}$and $-\mathrm{CH}_{3}$ groups modified anodes with different surface charges. It was found that the start-up time was the fastest in case of $\mathrm{N}^{+}\left(\mathrm{CH}_{3}\right)_{3}$ group (23 days), while the $-\mathrm{CH}_{3}$ modification resulted in a longest one (37.2 days) and furthermore, the more (positively) charged and more hydrophilic surfaces could better promote the selective and efficient exoelectrogenic biofilm development. In order to perform the surface modification, Feng et al. [112] suggested a method by using quaternary ammonium compound directly added to the anodic electrolyte in wastewater utilizing BES. Assessing the behavior of BESs, the startup time could be decreased by $29 \%$ and $21 \%$ using $0.01 \mathrm{M}$ and $0.001 \mathrm{M}$ quaternary ammonium concentration, respectively in comparison with the control system.

Besides the electrodes, the EXTERNAL RESISTANCE built in the electronic circuit of BES should be properly chosen, as well. In theory, the optimal value of external resistance should be close to the internal resistance of the bioelectrochemical system, which can improve the electrochemical performance e.g. in terms of current density [102]. In a study by Zhang et al. [113], the effect of static ohmic loadings on the biofilm formation and current production in MFC mode was sought. By using external resistance 
values of $10 \Omega, 50 \Omega, 250 \Omega$ and $1 \mathrm{k} \Omega$, it could be deducted that the lowest external resistance resulted in shorter start-up time (2.2 days) and highest current production. However, regarding the maximum power density, the external resistance of $50 \Omega$ (with a start-up time of 4.3 days) was found to be optimal because of the higher amount of active biomass formed.

The INTERNAL RESISTANCE of BES is dependent on factors such as electrode distances, solution (anolyte, catolyte) conductivity, electrode structures, etc. [62,74]. For example, the arrangement of the electrodes (anode, cathode) was shown to affect the internal resistance of the system $[67,70]$ and smaller electrode spacing was found to increase $\mathrm{H}_{2}$ production in MEC [114]. Therefore, constructional or in other words, architectural features of BES should be treated with care to minimize losses and enhance the performances [115-117]

Further considerations should be made regarding the MEMBRANE to be used in two-chambered arrangements, which represent the traditional design of bioelectrochmical systems. In such applications, the anodic and cathodic compartments are separated by various ion exchange membranes. In this regard, Rozendal et al. [90] compared cationic (CEM) and anionic exchange (AEM) membranes to be employed for such purposes. Using CEM, an issue with $\mathrm{pH}$ increase in the cathode side of the cell may be experienced due to migration of positively charged ions other than $\mathrm{H}^{+}$[118]. This phenomena depresses the system performance in a way that the higher $\mathrm{pH}$ gradients between anode and cathode cause greater potential losses. To overcome this problem, several different 
strategies were already tested [119] e.g. the deployment of AEM. In that case, biocatalyzed $\mathrm{H}_{2}$ production takes place from the reduction of water instead of via the recombination of protons with electrons [90]. Although membranes are recognized elements of classical BES, the construction of membrane-less systems may be suggested since the membrane itself acts as an ohmic resistance and thus, contributes to the overall internal resistance of the bioelectrochemical cell [49]. Moreover, the research of novel membrane separators can be taken as a way forward so as to improve the conductivity properties and facilitate more selective ion (proton) transport, which can expectedly lower internal resistances in the bioelectrochemical systems. From this point of view, recent findings demonstrated that membranes prepared with ionic liquids can be promising alternatives $[\mathbf{1 1 8 , 1 1 9 ]}$. Besides, according to Tartakovsky et al. [120], a realtime strategy for adjusting external voltage can be suggested after proper start-up in order to minimize internal MEC resistance, reduce power supply demand and simultaneously achieve optimal hydrogen formation rate.

\section{Concluding remarks}

Factors taking part in MEC start-up are inoculum selection and enrichment, operating conditions and cell architecture (Fig. 3). The analysis based on a wide range of literature studies has the message that MECs started-up with pure cultures are feasible for fundamental studies, while practical MECs dealing with problematic feedstock treatment 
and simultaneous energy $\left(\mathrm{H}_{2}\right)$ recovery rely typically on mixed communities. These, however, should be enriched and pretreated to attain a consortia with better electrochemical activity and to suppress the growth of competing, nonbioelectrochemical microorganisms. MECs - regardless of the type of inocula used - can be started-up in direct or indirect mode, where the latter means an MFC-based strategy for the development of sufficient anodic biofilms before their application for $\mathrm{H}_{2}$ production in MEC. Successful MEC start-up has to consider proper reactor operation (in terms of anodic potential, temperature, substrate concentration, etc.) without which the full potential of the electrochemically-active bioanodes remains unexploited and operational failures may be experienced over time. To obtain as high process efficiencies as possible, cell design taking into account electrode materials, external- and internal resistances, membranes (where applicable) ought to be of primary concern to aid start-up and subsequent, steady-state operation.

\section{Acknowledgement}

Péter Bakonyi acknowledges the support received from National Research, Development and Innovation Office (Hungary) under grant number PD 115640. The financial assistance to the first author (Gopalakrishnan Kumar) from Ton Duc Thang University, Vietnam is highly acknowledged. Dr. Periyasamy Sivagurunathan greatly acknowledges the financial contribution provided by the Japan Society for Promotion of 
Science (JSPS) postdoctoral fellowship. This work was supported by Korea Research Fellowship Program through the National Research Foundation of Korea (NRF) funded by the Ministry of Science, ICT and Future Planning. The study was supported by the Research Grant (FOSTECT.BR.17) from Ton Duc Thang University, Vietnam. The "GINOP-2.3.2-15 - Excellence of strategic R+D workshops (Development of modular, mobile water treatment systems and waste water treatment technologies based on University of Pannonia to enhance growing dynamic export of Hungary (2016-2020))" is thanked for supporting this work.

\section{References}

[1] Venkata Mohan S, Velvizhi G, Vamshi Krishna K, Lenin Babu M. Microbial catalyzed electrochemical systems: a bio-factory with multi-facet applications. Bioresour Technol 2004;165:355-64

[2] Wang H, Luo H, Fallgren PH, Jin S, Ren ZJ. Bioelectrochemical system platform for sustainable environmental remediation and energy generation. Biotechnol Adv $2015 ; 33: 317-34$

[3] Wang H, Jason Z. A comprehensive review on microbial electrochemical systems as a platform technology. Biotechnol Adv 2013;31:1796-807 
[4] Pant D, Singh A, Van Bogaert G, Olsen SI, Nigam PS, Diels L, et al. Bioelectrochemical systems (BES) for sustainable energy production and product recovery from organic wastes and industrial wastewaters. RSC Adv 2012;2:1248-63

[5] Logan BE, Hamelers B, Rozendal R, Schröder U, Keller J, Freguia S, et al. Microbial fuel cells: Methodology and technology. Environ Sci Technol 2006;40:5181-92

[6] Logan BE, Call D, Cheng S, Hamelers HVM, Sleutels THJA, Jeremiasse AW, et al. Microbial electrolysis cells for high yield hydrogen gas production from organic matter. Environ Sci Technol 2008;42:8630-40

[7] Sun M, Sheng GP, Zhang L, Xia CR, Mu ZX, Liu XW, et al. An MEC-MFC-coupled system for biohydrogen production from acetate. Environ Sci Technol 2008;42:8095-100

[8] Pant D, Van Bogaert G, Diels L, Vanbroekhoven K. A review of the substrates used in microbial fuel cells (MFCs) for sustainable energy production. Bioresour Technol 2010;101:1533-43

[9] Koók L, Rózsenberszki T, Nemestóthy N, Bélafi-Bakó K, Bakonyi P. Bioelectrochemical treatment of municipal waste liquor in microbial fuel cells for energy valorization. J Clean Prod 2016;112:4406-12

[10] Rózsenberszki T, Koók L, Hutvágner D, Nemestóhy N, Bélafi-Bakó K, Bakonyi P, et al. Comparison of anaerobic degradation processes for bioenergy generation from liquid fraction of pressed solid waste. Waste Biomass Valor 2015;6:465-73 
[11] Zhou M, Wang H, Hassett DJ, Gu T. Recent advances in microbial fueld cells (MFCs) and microbial electrolysis cells (MECs) for wastewater treatment, bioenergy and bioproducts. J Chem Technol Biotechnol 2013;88:508-18

[12] Rivera I, Buitrón G, Bakonyi P, Nemestóthy N, Bélafi-Bakó K. Hydrogen production in a microbial electrolysis cell fed with a dark fermentation effluent. J Appl Electrochem 2015;45:1223-9

[13] Foley JM, Rozendal RA, Hertle CR, Lant PA, Rabaey K. Life cycle assessment of high-rate anaerobic treatment, microbial fuel cells, and microbial electrolysis cells. Environ Sci Technol 2010;44:3629-37

[14] Rosenbaum M, Aulenta F, Villano M, Angenent LT. Cathodes as electron donors for microbial metabolism: which extracellular electron transfer mechanisms are involved?. Bioresour Technol 2011;102:324-33

[15] Liu W, Wang A, Cheng S, Logan BE, Yu H, Deng Y, et al. Geochip-based functional gene analysis of anodophilic communities in microbial electrolysis cells under different operational modes. Environ Sci Technol 2010;44:7729-35

[16] Bakonyi P, Nemestóthy N, Simon V, Bélafi-Bakó K. Review on the start-up experiences of continuous fermentative hydrogen producing bioreactors. Renew Sustain Energy Rev 2014;40:806-13

[17] Liu W, Wang A, Ren N, Zhao X, Liu L, Yu Z, et al. Electrochemically assisted biohydrogen production from acetate. Energy Fuels 2008;22:159-63 
[18] Michie IS, Kim JR, Dinsdale RM, Guwy AJ, Premier GC. Factors affecting microbial fuel cell acclimation and operation in temperate climates. Water Sci Technol $2013 ; 67: 2568-75$

[19] Ruiz V, Ilhan ZE, Kang DW, Krajmalnik-Brown R, Buitrón G. The source of inoculum plays a defining role in the development of MEC microbial consortia fed with acetic and propionic acid mixtures. J Biotechnol 2014;182-183:11-8

[20] Butti SK, Velvizhi G, Sulonen MLK, Haavisto JM, Koroglu EO, Cetinkaya AY, et al. Microbial electrochemical technologies with the perspective on harnessing bioenergy: Maneuvering towards upscaling. Renew Sustain Energy Rev 2016;53:462-76

[21] Hasany M, Mardanpour MM, Yaghmaei S. Biocatalysis in microbial electrolysis cells: A review. Int J Hydrogen Energy 2016;41:1477-93

[22] Kiely PD, Regan JM, Logan BE. The electric picnic: synergistic requirements for exoelectrogenic microbial communities. Curr Opin Biotechnol 2011;22:378-85

[23] Logan BE. Exoelectrogenic bacteria that power microbial fuel cells. Nature Rev Microbiol 2009;7:375-81

[24] Patil SA, Gildemyn S, Pant D, Zengler K, Logan BE, Rabaey K. A logical data presentation framework for electricity-driven bioproduction processes. Biotechnol Adv 2015;33:736-44

[25] Chabert N, Ali OA, Achouak W. All ecosystems potentially host electrogenic bacteria. Bioelectrochemistry 2015;106:88-96 
[26] Miceli JF, Parameswaran P, Kang DW, Krajmalnik-Brown R, Torres CI. Enrichment and analysis of anode-respiring bacteria from diverse anaerobic inocula. Environ Sci Technol 2012;46:10349-55

[27] Liu H, Hu H, Chignell J, Fan Y. Microbial electrolysis: novel technology for hydrogen production from biomass. Biofuels 2010;1:129-42

[28] Schröder U, Harnisch F, Angenent LT. Microbial electrochemistry and technology: terminology and classification. Energy Environ Sci 2015;8:513-9

[29] Sharma V, Kundu PP. Biocatalysts in microbial fuel cells. Enzyme Microb Tech $2010 ; 47: 179-88$

[30] Szöllősi A, Rezessy-Szabó JM, Hoschke Á, Nguyen QD. Novel method for screening of microbes for application in microbial fuel cells. Bioresour Technol 2015;179:123-7

[31] Kumar G, Bakonyi P, Kobayashi T, Xu KQ, Sivagurunathan P, Kim SH, et al. Enhancement of biofuel production via microbial augmentation: The case of dark fermentative hydrogen. Renew Sustain Energy Rev 2016;57:879-91

[32] Lovley DR. Microbial fuel cells: novel microbial physiologies and engineering approaches. Curr Opin Biotechnol 2006;17:327-32

[33] Gao Y, Ryu H, Santo Domingo JW, Lee HS. Syntrophic interactions between $\mathrm{H}_{2^{-}}$ scavenging and anode-respiring bacteria can improve current density in microbial electrochemical cells. Bioresour Technol 2014;153:245-53 
[34] Lobato J, Canizares P, Fernández FJ, Rodrigo MA. An evaluation of aerobic and anaerobic sludges as start-up material for microbial fuel cell systems. New Biotechnol 2012;29:415-20

[35] Liu Y, Harnisch F, Fricke K, Sietmann R, Schröder U. Improvement of the anodic bioelectrocatalytic activity of mixed culture biofilms by a simple consecutive electrochemical selection procedure. Biosens Bioelectron 2008;24:1006-11

[36] Pierra M, Carmona-Martínez AA, Trably E, Godon JJ, Bernet N. Microbial characterization of anode-respiring bacteria within biofilms developed from cultures previously enriched in dissimilatory metal-reducing bacteria. Bioresour Technol 2015;195:283-7

[37] Pierra M, Carmona-Martínez AA, Trably E, Godon JJ, Bernet N. Specific and efficient electrochemical selection of Geoalkalibacter subterraneus and Desulfuromonas acetoxidans in high current-producing biofilms. Bioelectrochemistry 2015;106:221-5

[38] Borjas Z, Ortiz JM, Aldaz A, Feliu J, Esteve-Núñez A. Strategies for reducing the start-up operation of microbial electrochemical treatments of urban wastewater. Energies $2015 ; 8: 14064-77$

[39] Sato C, Martinez RG, Shields MS, Perez-Gracia A, Schoen MP. Behaviour of microbial fuel cell in a start-up phase. Int J Environ Eng 2009;1:36-51

[40] Kim JR, Min B, Logan BE. Evaluation of procedures to acclimate a microbial fuel cell for electricity production. Appl Microbiol Biotechnol 2005;68:23-30 
[41] Wang A, Sun D, Ren N, Liu C, Logan BE, Wu WM. A rapid selection strategy from an anodophilic consortium for microbial fuel cells. Bioresour Technol 2010;101:5733-5

[42] Boghani HC, Kim JR, Dinsdale RM, Guwy AJ, Premier GC. Control of power sourced from a microbial fuel cell reduces its start-up time and increases bioelectrochemical activity. Bioresour Technol 2013;140:277-85

[43] Ren L, Zhang X, He W, Logan BE. High current densities enable exoelectrogens to outcompete aerobic heterotrophs for substrate. Biotechnol Bioeng 2014;111:2163-9

[44] Manuel MF, Neburchilov V, Wang H, Guiot SR, Tartakovsky B. Hydrogen production in a microbial electrolysis cell with nickel-based gas diffusion cathodes. $\mathbf{J}$ Power Sources 2010;195:5514-9

[45] Lee HS, Rittmann BE. Significance of biological hydrogen oxidation in a continuous single-chamber microbial electrolysis cell. Environ Sci Technol 2010;44:948-54

[46] Wang A, Liu W, Cheng S, Xing D, Zhou J, Logan BE. Source of methane and methods to control its formation in single chamber microbial electrolysis cell. Int $\mathbf{J}$ Hydrogen Energy 2009;34:3653-8

[47] Dhar BR, Elbeshbishy E, Hafez H, Lee HS. Hydrogen production from sugar beet juice using an integrated biohydrogen process of dark fermentation and microbial electrolysis cell. Bioresour Technol 2015;198:223-30 
[48] Montpart N, Ribot-Llobet E, Garlapati VK, Rago L, Baeza JA, Guisasola A. Methanol opportunities for electricity and hydrogen production in bioelectrochemical systems. Int J Hydrogen Energy 2014;39:770-7

[49] $\mathrm{Hu} \mathrm{H}$, Fan Y, Liu H. Hydrogen production using single-chamber membrane-free microbial electrolysis cells. Water Res 2008;42:4172-8

[50] Villano M, Aulenta F, Ciucci C, Ferri T, Giuliano A, Majone M. Bioelectrochemical reduction of $\mathrm{CO}_{2}$ to $\mathrm{CH}_{4}$ via direct and indirect extracellular electron transfer by a hydrogenophilic methanogenic culture. Bioresour Technol 2010;10:3085-90

[51] Zhen G, Lu X, Kobayashi T, Kumar G, Xu K. Promoted electromethanosynthesis in a two-chamber microbial electrolysis cells (MECs) containing a hybrid biocathode covered with graphite felt (GF). Chem Eng J 2016;284:1146-55

[52] Zhen G, Kobayashi T, Lu X, Xu K. Understanding methane bioelectrosynthesis from carbon dioxide in a two-chamber microbial electrolysis cells (MECs) containing a carbon biocathode. Bioresour Technol 2015;186:141-8

[53] Sun M, Zhai LF, Li WW, Yu HQ. Harvest and utilization of chemical energy in wastes by microbial fuel cells. Chem Soc Rev 2016;45:2847-70

[54] Ruiz Y, Baeza JA, Guisasola A. Revealing the proliferation of hydrogen scavengers in a single-chamber microbial electrolysis cell using electron balances. Int $\mathbf{J}$ Hydrogen Energy 2013;38:15917-27 
[55] Sleutels THJA, Darus L, Hamelers HVM, Buisman CJN. Effect of operational parameters on Coulombic efficiency in bioelectrochemical systems. Bioresour Technol 2011;102:11172-6

[56] Carmona-Martínez AA, Harnisch F, Kuhlicke U, Neu TR, Schröder U. Electron transfer and biofilm formation of Shewanella putrefaciens as a function of anode potential. Bioelectrochemistry 2013;93:23-9

[57] Call D, Logan BE. Hydrogen production in a single chamber microbial electrolysis cell lacking a membrane. Environ Sci Technol 2008;42:3401-6

[58] Chae KJ, Choi MJ, Lee J, Ajayi FF, Kim IS. Biohydrogen production via biocatalyzed electrolysis in acetate-fed bioelectrochemical cells and microbial community analysis. Int J Hydrogen Energy 2008;33:5184-92

[59] Bakonyi P, Borza B, Orlovits K, Simon V, Nemestóthy N, Bélafi-Bakó K. Fermentative hydrogen production by conventionally and unconventionally heat pretreated seed cultures: A comparative assessment. Int $\mathrm{J}$ Hydrogen Energy 2014;39:5589-96

[60] Catal T, Lesnik KL, Liu H. Suppression of methanogenesis for hydrogen production in singlechamber microbial electrolysis cells using various antibiotics. Bioresour Technol $2015 ; 187: 77-83$

[61] Fang HHP, Liu H. Effect of $\mathrm{pH}$ on hydrogen production from glucose by a mixed culture. Bioresour Technol 2002;82:87-93 
[62] Logan BE, Regan JM. Electricity-producing bacterial communities in microbial fuel cells. Trends Microbiol 2006;14:512-8

[63] Escapa A, Manuel MF, Morán A, Gómez X, Guiot SR, Tartakovsky B. Hydrogen production from glycerol in a membraneless microbial electrolysis cell. Energy Fuels $2009 ; 23: 4612-8$

[64] Selembo PA, Perez JM, Lloyd WA. Logan BE. High hydrogen production from glycerol or glucose by electrohydrogenesis using microbial electrolysis cells. Int $\mathbf{J}$ Hydrogen Energy 2009;34:5373-81

[65] Nam JY, Tokash JC, Logan BE. Comparison of microbial electrolysis cells operated with added voltage or by setting the anode potential. Int $\mathbf{J}$ Hydrogen Energy 2011;36:10550-6

[66] Ren NQ, et al. Biohydrogen production by fermentation and microbial electrolysis cells. In "Environmental anaerobic technology - Application and new developments", Ed. Fang HHP. Imperial College Press, London, 2010

[67] Liang DW, Peng SK, Lu SF, Liu YY, Lan F, Xiang Y. Enhancement of hydrogen production in a single chamber microbial electrolysis cell through anode arrangement optimization. Bioresour Technol 2011;102:10881-5

[68] Wang Q, Huang L, Pan Y, Zhou P, Quan X, Logan BE, et al. Cooperative cathode electrode and in situ deposited copper for subsequent enhanced $\mathrm{Cd}(\mathrm{II})$ removal and hydrogen evolution in bioelectrochemical systems. Bioresour Technol 2016;200:565-71 
[69] Escapa A, Gil-Carrera L, García V, Morán A. Performance of a continuous flow microbial electrolysis cell (MEC) fed with domestic wastewater. Bioresour Technol 2012;117:55-62

[70] Tartakovsky B, Manuel MF, Wang H, Guiot SR. High rate membrane-less microbial electrolysis cell for continuous hydrogen production. Int $\mathrm{J}$ Hydrogen Energy 2009;34:672-7

[71] Liu G, Yates MD, Cheng S, Call DF, Sun D, Logan BE. Examination of microbial fuel cell start-up times with domestic wastewater and additional amendments. Bioresour Technol 2011;102:7301-6

[72] Molognoni D, Puig S, Balaguer MD, Liberale A, Capodaglio AG, Callegari A, et al. Reducing start-up time and minimizing energy losses of microbial fuel cells using maximum power point tracking strategy. J Power Sources 2014;269:403-11

[73] Wang X, Feng Y, Ren N, Wang H, Lee H, Li N, et al. Accelerated start-up of twochambered microbial fuel cells: Effect of anodic positive poised potential. Electrochim Acta 2009;54:1109-14

[74] Verea L, Savadogo O, Verde A, Campos J, Ginez F, Sebastian PJ. Performance of a microbial electrolysis cell (MEC) for hydrogen production with a new process for the biofilm formation. Int J Hydrogen Energy 2014;39:8938-46 
[75] Carmona-Martínez AA, Trably E, Milferstedt K, Lacroix R, Etcheverry L, Bernet N. Long-term continuous operation of $\mathrm{H} 2$ in microbial electrolysis cell (MEC) treating saline wastewater. Water Res 2015;81:149-56

[76] Venkata Mohan S, Lenin Babu M. Dehydrogenase activity in association with poised potential during biohydrogen production in single chamber microbial electrolysis cell. Bioresour Technol 2011;102:8457-65

[77] Wagner RC, Call FD, Logan BE. Optimal set anode potentials vary in bioelectrochemical systems. Environ Sci Technol 2010;44:6036-41

[78] Torres CI, Krajmalnik-Brown R, Parameswaran P, Marcus AK, Wanger G, Gorby YA, et al. Selecting anode-respiring bacteria based on anode potential: phylogenetic, electrochemical, and microscopic characterization. Environ Sci Technol 2009;43:9519-24 [79] Busalmen JP, Esteve-Nunez A, Feliu JM. Whole cell electrochemistry of electricityproducing microorganisms evidence an adaptation for optimal exocellular electron transport. Environ Sci Technol 2008;42:2445-50

[80] Liu H, Matsuda S, Kato S, Hashimoto K, Nakanishi S. Redox-responsive switching in bacterial respiratory pathways involving extracellular electron transfer. ChemSusChem 2010;3:1253-6

[81] Liu H, Matsuda S, Kawai T, Hashimoto K, Nakanishi S. Feedback stabilization involving redox states of c-type cytochromes in living bacteria. Chem Commun $2011 ; 47: 3870-2$ 
[82] Cho EJ, Ellington AD. Optimization of the biological component of a bioelectrochemical cell. Bioelectrochemistry 2007;70:165-72

[83] Aelterman P, Freguia S, Keller J, Verstraete W, Rabaey K. The anode potential regulates bacterial activity in microbial fuel cells. Appl Microbiol Biotechnol 2008;78:409-18

[84] Commault AS, Lear G, Packer MA, Weld RJ. Influence of anode potentials on selection of Geobacter strains in microbial electrolysis cells. Bioresour Technol 2013;139:226-34

[85] Harris HW, El-Naggar MY, Bretschger O, Ward MJ, Romine MF Obraztsova AY, et al. Electrokinesis is a microbial behavior that requires extracellular electron transport. Proc Natl Acad Sci USA 2010;107:326-31

[86] Villano M, Aulenta F, Beccari M, Majone M. Start-up and performance of an activated sludge bioanode in microbial electrolysis cells. Chem Eng Trans 2012;27:109114. doi: 10.3303/CET1227019

[87] Heidrich ES, Dolfing J, Scott K, Edwards SR, Jones C, Curtis TP. Production of hydrogen from domestic wastewater in a pilot-scale microbial electrolysis cell. Appl Microbiol Biotechnol 2013;97:6979-89

[88] Heidrich ES, Edwards SR, Dolfing J, Cotterill SE, Curtis TP. Performance of a pilot scale microbial electrolysis cell fed on domestic wastewater at ambient temperatures for a 12 month period. Bioresour Technol 2014;173:87-95 
[89] Jeremiasse AW, Hamerers HVM, Saakes M, Buisman CJN. Ni foam cathode enables high volumetric $\mathrm{H}_{2}$ production in a microbial electrolysis cell. Int $\mathbf{J}$ Hydrogen Energy 2010;35:12716-23

[90] Rozendal RA, Hamelers HVM, Molenkamp RJ, Buisman CJN. Performance of single chamber biocatalyzed electrolysis with different types of ion exchange membranes. Water Res 2007;41:1984-94

[91] Wang A, Liu W, Ren N, Zhou J, Cheng S. Key factors affecting microbial anode potential in a microbial electrolysis cell for $\mathrm{H}_{2}$ production. Int $\mathrm{J}$ Hydrogen Energy 2010;35:13481-7

[92] Wang A, Liu W, Ren N, Cheng H, Lee DJ. Reduced internal resistance of microbial electrolysis cell (MEC) as factors of configuration and stuffing with granular activated carbon. Int J Hydrogen Energy 2010;35:13488-92

[93] Michie IS, Kim JR, Dinsdale RM, Guwy AJ, Premier GC. The influence of psychrophilic and mesophilic start-up temperature on microbial fuel cell system performance. Energy Environ Sci 2011;4:1011-9

[94] Michie IS, Kim JR, Dinsdale RM, Guwy AJ, Premier GC. Operational temperature regulates anodic biofilm growth and the development of electrogenic activity. Appl Microbiol Biotechnol 2011;92:419-30 
[95] Patil SA, Harnisch F, Kapadnis B, Schröder U. Electroactive mixed culture biofilms in microbial bioelectrochemical systems: the role of temperature for biofilm formation and performance. Biosens Bioelectron 2010;26:803-8

[96] Lu L, Ren N, Zhao X, Wang H, Wu D, Xing D. Hydrogen production, methanogen inhibition and microbial community structures in psychrophilic single-chamber microbial electrolysis cells. Energy Environ Sci 2011;4:1329-36

[97] Kadier A, Simayi Y, Kalil MS, Abdeshahian P, Hamid AA. A review of the substrates used in microbial electrolysis cells (MECs) for producing sustainable and clean hydrogen gas. Renew Energy 2014;71:466-72

[98] Li XH, Liang DW, Bai YX, Fan YT, Hou HW. Enhanced $\mathrm{H}_{2}$ production from corn stalk by integrating dark fermentation and single chamber microbial electrolysis cells with double anode arrangement. Int J Hydrogen Energy 2014;39:8977-82

[99] Lalaurette E, Thammannagowda S, Mohagheghi A, Maness PC, Logan BE. Hydrogen production from cellulose in a two-stage process combining fermentation and electrohydrogenesis. Int J Hydrogen Energy 2009;34:6201-10

[100] Jeremiasse AW, Hamelers HV, Buisman CJ. Microbial electrolysis cell with a microbial biocathode. Bioelectrochemistry 2010;78:39-43

[101] Jeremiasse AW, Hamelers HV, Croese E, Buisman CJ. Acetate enhances startup of a $\mathrm{H}_{2}$-producing microbial biocathode. Biotechnol Bioeng 2012;109:657-64 
[102] Aelterman P, Versichele M, Marzorati M, Boon N, Verstraete W. Loading rate and external resistance control the electricity generation of microbial fuel cells with different three-dimensional anodes. Bioresour Technol 2008;99:8895-902

[103] Zhou M, Chi M, Luo J, He H, Jin T. An overview of the electrode materials in microbial fuel cells. J Power Sources 2011;196:4427-35

[104] Zheng, S, Yang F, Chen S, Liu L, Xiong Q, Yu T, et al. Binder-free carbon black/stainless steel mesh composite electrode for high-performance anode in microbial fuel cells. J Power Sources 2015;284:252-7

[105] Call DF, Merrill MD, Logan BE. High surface area stainless steel brushes as cathodes in microbial electrolysis cells. Environ Sci Technol 2009;43:2179-83

[106] Kalathil S, Khan MM, Lee J, Cho MH. Production of bioelectricity, bio-hydrogen, high value chemicals and bioinspired nanomaterials by electrochemically active biofilms. Biotechnol Adv 2013;31:915-24

[107] Kundu A, Sahu JN, Redzwan G, Hashim MA. An overview of cathode material and catalysts suitable for generating hydrogen in microbial electrolysis cell. Int J Hydrogen Energy 2013;38:1745-57

[108] Zhang Y, Merrill MD, Logan BE. The use and optimization of stainless steel mesh cathodes in microbial electrolysis cells. Int J Hydrogen Energy 2010;35:12020-8 
[109] Batlle-Vilanova P, Puig S, Gonzales-Olmos R, Vilajeliu-Pons A, Bañeras L, Dolors Balaguer M, et al. Assessment of biotic and abiotic graphite cathodes for hydrogen production in microbial electrolysis cells. Int J Hydrogen Energy 2014;39:1297-305

[110] Sleutels THJA, Hamelers HVM, Buisman CJN. Effect of mass and charge transport speed and direction in porous anodes on microbial electrolysis cell performance. Bioresour Technol 2011;102:399-403

[111] Guo K, Freguia S, Dennis PG, Chen X, Donose BC, Keller J, Gooding JJ, Rabaey K. Effects of surface charge and hydrophobicity on anodic biofilm formation, community composition, and current generation in bioelectrochemical systems. Environ Sci Technol $2013 ; 47: 7563-70$

[112] Feng C, Liu Y, Li Q, Che Y, Li N, Wang X. Quaternary ammonium compound in anolyte without functionalization accelerates the startup of bioelectrochemical systems using real wastewater. Electrochim Acta 2016;188:801-8

[113] Zhang L, Zhu X, Li J, Liao Q, Ye D. Biofilm formation and electricity generation of a microbial fuel cell started up under different external resistances. J Power Sources 2011;196:6029-35

[114] Cheng S, Logan BE. High hydrogen production rate of microbial electrolysis cell (MEC) with reduced elecrode spacing. Bioresour Technol 2011;102:3571-4 
[115] Clauwaert P, Aelterman P, Pham TH, Schamphelaire LD, Carballa M, Rabaey K, et al. Minimizing losses in bio-electrochemical systems: the road to applications. Appl Microbiol Biotechnol 2008;79:901-13

[116] Gil-Carrera L, Mehta P, Escapa A, Morán A, García V, Guiot SR, et al. Optimizing the electrode size and arrangement in microbial electrolysis cell. Bioresour Technol $2011 ; 102: 9593-8$

[117] Harnisch F, Schröder U. Selectiviy versus mobility: separation of anode and cathode in microbial bioelectrochemical systems. ChemSusChem 2009;2:921-6

[118] Hernández-Fernández FJ, Pérez de los Ríos A, Mateo-Ramírez F, Juarez MD, Lozano-Blanco LJ, Godínez C. New application of polymer inclusion membrane based on ionic liquids as proton exchange membrane in microbial fuel cell. Sep Purif Technol 2016;160:51-8

[119] Hernández-Fernández FJ, Pérez de los Ríos A, Mateo-Ramírez F, Godínez C, Lozano-Blanco LJ, Moreno JI, Tomás-Alonso F. New application of supported ionic liquid membranes as proton exchange membranes in microbial fuel cell for waste water treatment. Chem Eng J 2015;279:115-9

[120] Tartakovsky B, Mehta P, Santoyo G, Guiot SR. Maximizing hydrogen production in a microbial electrolysis cell by real-time optimization of applied voltage. Int $\mathbf{J}$ Hydrogen Energy 2011;36:10557-64 
[121] Ahn Y, Logan BE. Effectiveness of domestic wastewater treatment using microbial fuel cells at ambient and mesophilic temperaturas. Bioresour Technol 2010;101:469-75 [122] Zhen G, Kobayashi T, Lu X, Kumar G, Hu Y, Bakonyi P, et al. Recovery of biohydrogen in a single-chamber microbial electrohydrogenesis cell using liquid fraction of pressed municipal solid waste (LPW) as substrate. International Journal of Hydrogen Energy (2016), http://dx.doi.org/10.1016/j.ijhydene.2016.07.112 
Table 1 - Constructional features of MECs for system start-up

\begin{tabular}{|c|c|c|c|c|c|c|c|c|c|}
\hline $\begin{array}{l}\text { Start-up } \\
\text { mode }\end{array}$ & Cell design & Membrane & Inoculum & Substrate & $\begin{array}{l}\text { Anode } \\
\text { material }\end{array}$ & $\begin{array}{l}\text { Cathode } \\
\text { material }\end{array}$ & Anolyte & Catholyte & Reference \\
\hline direct & two chamber & $\begin{array}{l}\text { Nafion }^{\circledR} 117 \\
\text { PEM }\end{array}$ & activated sludge & Na-acetate & $\begin{array}{l}\text { graphite } \\
\text { granules }\end{array}$ & $\begin{array}{l}\text { graphite } \\
\text { granules }\end{array}$ & $\begin{array}{l}\text { anaerobic basal } \\
\text { medium (pH: 7- } \\
7.5)\end{array}$ & $\begin{array}{c}\text { anaerobic basal } \\
\text { medium (pH: 7-7.5) }\end{array}$ & [86] \\
\hline direct & two chamber & Rhinohide $^{\circledR}$ & $\begin{array}{l}\text { indigenous } \\
\text { wastewater } \\
\text { microflora }\end{array}$ & $\begin{array}{c}\text { municipal } \\
\text { wastewater }\end{array}$ & $\begin{array}{l}\text { carbon } \\
\text { felt }\end{array}$ & $\begin{array}{l}\text { stainless steel } \\
\text { wool }\end{array}$ & N.A. & $\begin{array}{l}\text { sterilized phosphate } \\
\text { buffer }(50 \mathrm{mM}, \mathrm{pH} \text { : } \\
7)\end{array}$ & [88] \\
\hline direct & two chamber & $\begin{array}{l}\text { Neosepta }^{\circledR} \\
\text { AEM }\end{array}$ & MEC effluent & Na-acetate & $\begin{array}{l}\text { graphite } \\
\text { felt }\end{array}$ & $\mathrm{Ni}$ foam & $\begin{array}{l}\text { microbial nutrient } \\
\text { medium }\end{array}$ & $0.1 \mathrm{M} \mathrm{KCl}$ & [89] \\
\hline direct & two chamber & $\begin{array}{l}\text { Nafion }^{\circledR} 117 \\
\text { PEM }\end{array}$ & activated sludge & Na-acetate & $\begin{array}{l}\text { carbon } \\
\text { cloth }\end{array}$ & $\begin{array}{l}\text { carbon paper } \\
\quad \text { with } \mathrm{Pt}\end{array}$ & $\begin{array}{l}\text { nutrient solution } \\
\quad(\mathrm{pH}: 6.9)\end{array}$ & $\begin{array}{c}\text { phosphate buffer (50 } \\
\text { mM, pH: 7) }\end{array}$ & [92] \\
\hline direct & two chamber & $\begin{array}{l}\text { Nafion }^{\circledR} 117 \\
\text { PEM }\end{array}$ & sewage sludge & Na-acetate & $\begin{array}{l}\text { carbon } \\
\text { cloth }\end{array}$ & $\begin{array}{l}\text { carbon paper } \\
\text { with } \mathrm{Pt}\end{array}$ & $\begin{array}{l}\text { nutrient solution } \\
\quad(\mathrm{pH}: 7)\end{array}$ & $\begin{array}{l}\text { sterilized phosphate } \\
\text { buffer (10 mM, pH: } \\
7)\end{array}$ & [91] \\
\hline
\end{tabular}




\begin{tabular}{|c|c|c|c|c|c|c|c|}
\hline direct & $\begin{array}{c}\text { two } \\
\text { chambers } \\
\text { operated in } \\
\text { single } \\
\text { chamber } \\
\text { configuration }\end{array}$ & $\begin{array}{l}\text { Fumasep }^{\circledR} \\
\text { FAB AEM }\end{array}$ & $\begin{array}{l}\text { bioelectrochemically } \\
\text {-active culture }\end{array}$ & Na-acetate & $\begin{array}{l}\text { graphite } \\
\text { felt }\end{array}$ & $\begin{array}{l}\text { Pt coated } \mathrm{Ti} \\
\text { mesh }\end{array}$ & $\begin{array}{c}\text { only for gas } \\
\text { collection purposes } \\
\text { (no liquid catholyte) }\end{array}$ \\
\hline direct & $\begin{array}{l}\text { single } \\
\text { chamber }\end{array}$ & - & anaerobic sludge & Na-acetate & $\begin{array}{c}\text { carbon } \\
\text { felt }\end{array}$ & $\begin{array}{l}\text { gas diffusion } \\
\text { Ni catalyst }\end{array}$ & nutrient solution \\
\hline direct & $\begin{array}{l}\text { single } \\
\text { chamber }\end{array}$ & - & anaerobic sludge & $\begin{array}{l}\text { (i) } \mathrm{Na}- \\
\text { acetate, (ii) } \\
\text { synthetic } \\
\text { wastewater }\end{array}$ & $\begin{array}{l}\text { carbon } \\
\text { felt }\end{array}$ & $\begin{array}{l}\text { carbon paper } \\
\text { with } \mathrm{Ni}\end{array}$ & $\begin{array}{l}\text { (i) acetate based nutrient solution, (ii) } \\
\text { synthetic wastewater }\end{array}$ \\
\hline direct & $\begin{array}{l}\text { single } \\
\text { chamber }\end{array}$ & - & $\begin{array}{l}\text { enriched anaerobic } \\
\text { sludge }\end{array}$ & glucose & $\begin{array}{l}\text { graphite } \\
\text { plate }\end{array}$ & graphite plate & designed synthetic wastewater \\
\hline direct/indirect & $\begin{array}{l}\text { single } \\
\text { chamber }\end{array}$ & - & $\begin{array}{c}\text { municipal } \\
\text { wastewater }\end{array}$ & Na-acetate & $\begin{array}{l}\text { carbon } \\
\text { cloth }\end{array}$ & $\begin{array}{l}\text { modified } \\
\text { carbon cloth }\end{array}$ & $\begin{array}{l}\text { mixture of phosphate buffer }(50 \mathrm{mM}, \mathrm{pH} \text { : } \\
7.0) \text { and nutrient solution }\end{array}$ \\
\hline indirect & $\begin{array}{l}\text { single } \\
\text { chamber }\end{array}$ & - & MFC effluent & Na-acetate & $\begin{array}{l}\text { graphite } \\
\text { fiber } \\
\text { brush }\end{array}$ & $\begin{array}{l}\text { platinized } \\
\text { carbon cloth }\end{array}$ & $\begin{array}{l}\text { mixture of phosphate buffer }(50,200 \\
\mathrm{mM}, \mathrm{pH}: 7.0) \text { and nutrient solution }\end{array}$ \\
\hline indirect & $\begin{array}{l}\text { single } \\
\text { chamber }\end{array}$ & - & wastewater & Na-acetate & $\begin{array}{l}\text { graphite } \\
\text { brush }\end{array}$ & $\begin{array}{l}\text { carbon cloth } \\
\text { with Pt layer }\end{array}$ & $\begin{array}{l}\text { mixture of phosphate buffer }(50,200 \\
\mathrm{mM}, \mathrm{pH}: 7.0) \text { and nutrient solution }\end{array}$ \\
\hline
\end{tabular}




\begin{tabular}{|c|c|c|c|c|c|c|c|}
\hline indirect & $\begin{array}{l}\text { single } \\
\text { chamber }\end{array}$ & - & wastewater & Na-acetate & $\begin{array}{l}\text { graphtite } \\
\text { felt }\end{array}$ & $\begin{array}{l}\text { carbon cloth } \\
\text { with Pt layer }\end{array}$ & $\begin{array}{c}\text { mixture of phosphate buffer }(50 \mathrm{mM}, \mathrm{pH} \text { : } \\
7.0) \text { and nutrient solution }\end{array}$ \\
\hline indirect & $\begin{array}{l}\text { single } \\
\text { chamber }\end{array}$ & - & $\begin{array}{l}\text { heat-treated anerobic } \\
\text { sludge }\end{array}$ & glycerol & $\begin{array}{l}\text { graphtite } \\
\text { felt }\end{array}$ & $\begin{array}{l}\text { gas diffusion } \\
\text { cathode with } \\
\mathrm{Pt}\end{array}$ & gas-phase cathode \\
\hline indirect & two chamber & $\begin{array}{l}\text { CMI-7000 } \\
\text { CEM }\end{array}$ & $\begin{array}{c}\text { municipal } \\
\text { wastewater }\end{array}$ & $\begin{array}{c}\text { dark } \\
\text { fermentation } \\
\text { effluent }\end{array}$ & $\begin{array}{l}\text { graphite } \\
\text { cloth }\end{array}$ & $\begin{array}{l}\text { carbon paper } \\
\text { with } \mathrm{Pt}\end{array}$ & $\begin{array}{cc}\text { synthetic and real } \\
\begin{array}{c}\text { dark fermentation } \\
\text { effluent }\end{array}\end{array} \begin{array}{c}\text { phosphate buffer (50 } \\
\mathrm{mM}, \mathrm{pH}: 7)\end{array}$ \\
\hline indirect & $\begin{array}{l}\text { single } \\
\text { chamber }\end{array}$ & - & anaerobic sludge & Na-acetate & $\begin{array}{l}\text { carbon } \\
\text { cloth }\end{array}$ & $\begin{array}{l}\text { Pt containing } \\
\text { cathode }\end{array}$ & synthetic wastewater (pH: 9) \\
\hline indirect & $\begin{array}{l}\text { single } \\
\text { chamber }\end{array}$ & - & $\begin{array}{l}\mathrm{H}_{2} \text { fermentation } \\
\text { effluent }\end{array}$ & $\begin{array}{c}\text { Na-acetate in } \\
\text { start-up, later } \\
\text { dark } \\
\text { fermentation } \\
\text { effluent }\end{array}$ & $\begin{array}{l}\text { graphtite } \\
\text { felt }\end{array}$ & $\begin{array}{l}\text { carbon cloth } \\
\text { with Pt layer }\end{array}$ & $\begin{array}{c}\text { mixture of phosphate buffer }(50 \mathrm{mM}, \mathrm{pH} \text { : } \\
7.0) \text { and nutrient solution }\end{array}$ \\
\hline
\end{tabular}


Fig. 1 - Principles of $\mathbf{H}_{2}$ production in microbial electrolysis cell

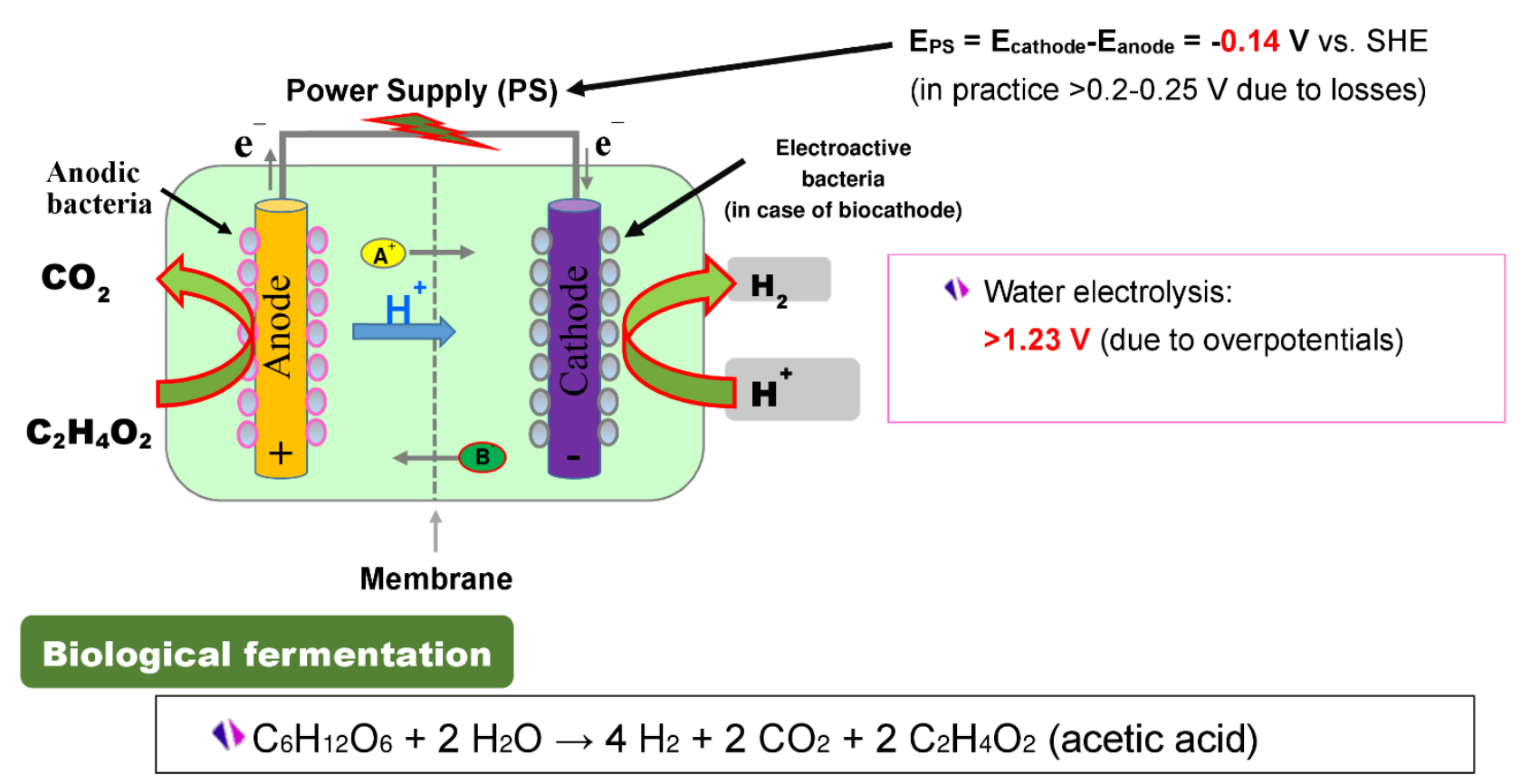

\section{MEC process}

1) Anode: $\mathrm{C}_{2} \mathrm{H}_{4} \mathrm{O}_{2}+2 \mathrm{H}_{2} \mathrm{O} \rightarrow 2 \mathrm{CO}_{2}+8 \mathrm{H}^{+}+8 \mathrm{e}^{-} \quad \mathrm{E}_{\text {anode }}=-0.279 \mathrm{Vvs}$. SHE

1) Cathode: $8 \mathrm{H}^{+}+8 \mathrm{e}^{-} \rightarrow 4 \mathrm{H}_{2} \quad \mathrm{E}_{\text {cathode }}=-0.414 \mathrm{~V}$ vs. SHE 
Fig. 2 - Possible methane-forming side-reactions in single-chamber MEC

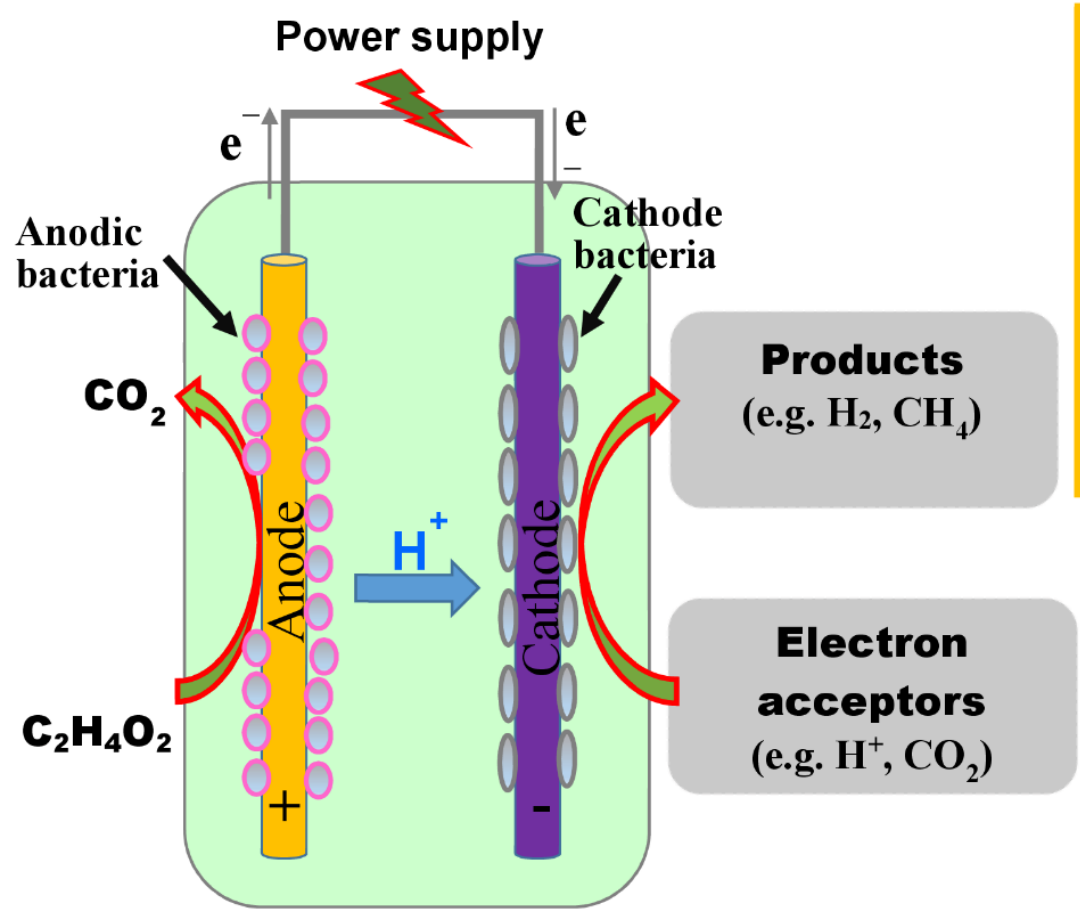

\section{Direct $E \mathbf{T}^{\mathrm{a}}$}

4 $\mathrm{CO}_{2}+8 \mathrm{H}^{+}+8 \mathrm{e}^{-} \rightarrow \mathrm{CH}_{4}+2 \mathrm{H}_{2} \mathrm{O}, \mathrm{E}=-0.244 \mathrm{~V}$ vs. SHE

\section{Bioelectrosynthesis}

${ }^{a}$ EET: extracellular electron transfer

2. Indirect $E \equiv T$

1) $2 \mathrm{H}^{+}+2 \mathrm{e}^{-} \rightarrow \mathrm{H}_{2}, \mathrm{E}=-0.410 \mathrm{~V}$ vs. SHE

4 $4 \mathrm{H}_{2}+\mathrm{CO}_{2} \rightarrow \mathrm{CH}_{4}+2 \mathrm{H}_{2} \mathrm{O}, \Delta \mathrm{G}^{\prime}=131 \mathrm{~kJ} / \mathrm{mol}$

Hydrogenotrophic methanogenesis 


\section{Fig. 3 - Aspects to consider for MEC start-up}

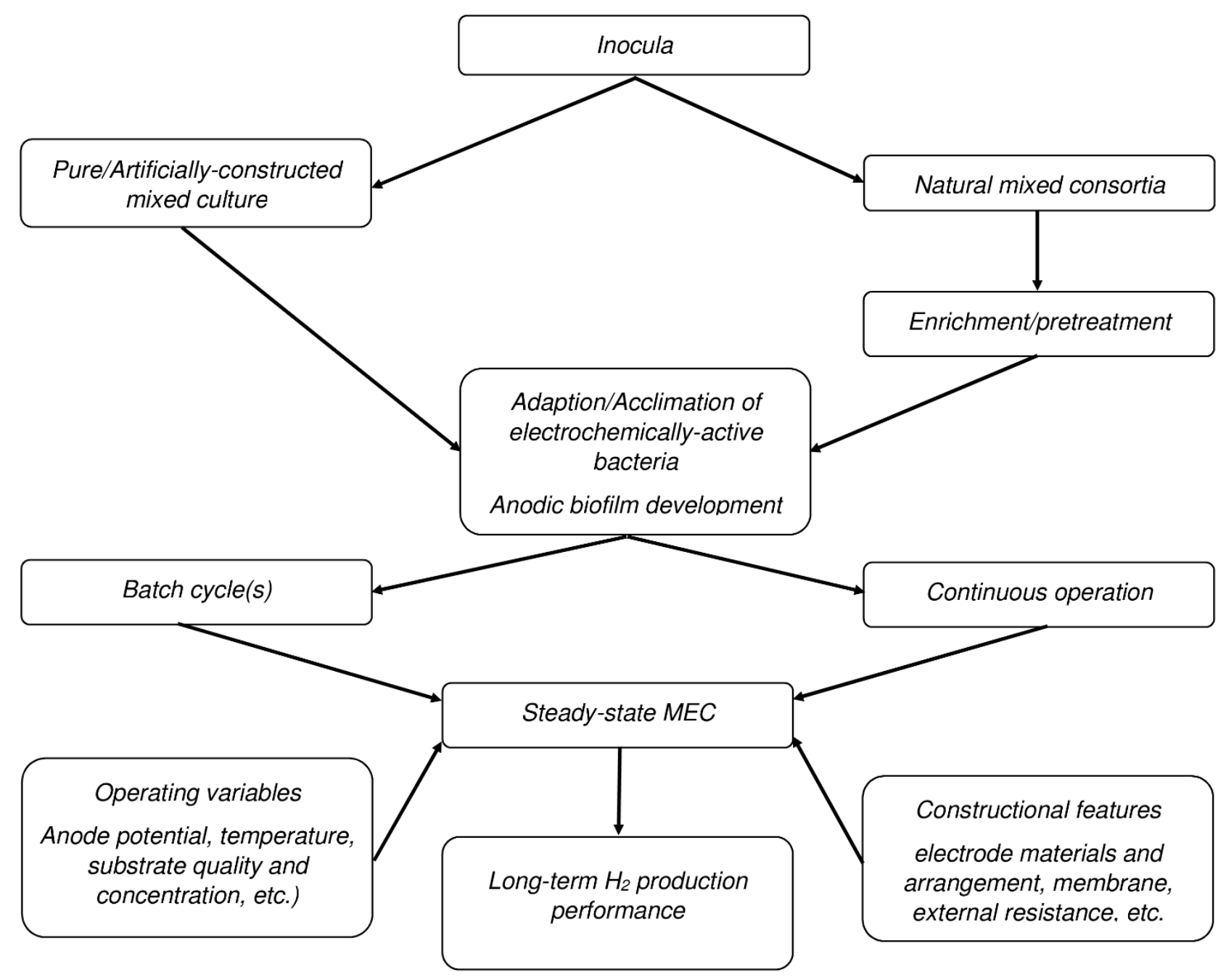

